\title{
Peningkatan Literasi Anak Melalui Program Ibu Baca Di Bangunjiwo Barat
}

\author{
Lanoke Intan Paradita1*, Fitria Rahmawati² \\ 1. Pendidikan Bahasa Arab, Fakultas Pendidikan Bahasa, Universitas Muhammadiyah Yogyakarta \\ ${ }^{2}$ Pendidikan Bahasa Inggris, Fakultas Pendidikan Bahasa Universitas Muhammadiyah Yogyakarta \\ Email: lamoke.ip@umy.ac.id \\ DOI: $10.18196 / p p m \cdot 34.293$
}

\begin{abstract}
Abstrak
Program Ibu Baca merupakan kegiatan pengabdian yang bertujuan untuk mendukung peningkatan literasi anak melalui penguatan literasi ibu. Kegiatan yang dilakukan adalah penguatan kemampuan ibu untuk membacakan nyaring sebagai salah satu strategi untuk menumbuhkan minat baca anak. Sasaran dari program ini adalah ibu-ibu Pengurus Ranting Aisyiyah Bangunjiwo Barat dan guru TK/KB yang dibawah naungan PRA Bangunjiwo Barat. Metode yang digunakan dalam kegiatan ini adalah pelatihan, praktik secara langsung dan juga pendampingan. Hasil dari kegiatan ini adalah pemahaman ibu terhadap membaca nyaring dan kegunaannya, praktik membaca nyaring dalam keluarga, serta manfaat langsung dari membaca nyaring yang didapat orang tua dan anak.
\end{abstract}

Kata Kunci: membaca nyaring, literasi anak, literasi keluarga

\section{Pendahuluan}

Penumbuhan minat baca merupakan sebuah fundamen untuk meningkatkan literasi sebuah bangsa. Berawal dari kemampuan membaca dan menulis, seseorang akan mampu mengembangkan kemampuan literasi lainnya seperti literasi numerasi, sains, finansial, digital, dan kebudayaan dan kewarganegaraan. Oleh karena itu, kemampuan membaca dan menulis perlu dikembangkan semenjak dini. Dalam bukunya yang berjudul The Read-Aloud Handbook, Jim Trelease (2013) menuliskan "We must take care that children's early encounters with reading are painless enough so they will cheerfully return to the experience now and forever. But if it's repeatedly painful, we will end up creating a school-time reader instead of a lifetime reader." Kutipan ini mengungkapkan bahwa untuk menumbuhkan kecintaan anak-anak terhadap membaca, mereka perlu memiliki pengalaman membaca yang menyenangkan secara berkelanjutan agar dapat membentuk mereka sebagai pembaca sepanjang hayat.

Pembiasaan ini tentunya perlu menjadi norma dalam setiap keluarga karena pendidikan anak-anak dimulai dari keluarga. Selain itu dukungan dari pemerintah dan masyarakat dalam lingkup yang lebih luas seperti komunitas maupun lembaga pendidikan juga diperlukan. Upayaupaya peningkatan literasi sudah dilakukan seperti adanya peraturan pemerintah tentang pembiasaan membaca melalui Gerakan Literasi Nasional dan Gerakan Literasi Sekolah yang memberikan siswa waktu khusus selama 15 menit sebelum memulai pelajaran untuk membaca buku non-teks (https://gln.kemdikbud.go.id/glnsite/tentang-gln/). Selain itu, terdapat beragam kegiatan literasi lainnya yang dilakukan oleh komunitas-komunitas literasi di Indonesia, seperti Mata Aksara, Reading Bugs, Let's Read Asia, yang memberikan edukasi terkait pentingnya literasi dalm keluarga melalui penyediaan sumber bacaan, alternatif kegiatan literasi bagi anak-anak serta pelibatan orang tua dalam kegiatan tersebut.

Program Ibu Baca yang dilakukan dalam pengabdian inipun merupakan salah satu kegiatan yang dilakukan dalam mendukung upaya bersama untuk meningkatkan tingkat literasi anak. Fokus program ini adalah edukasi dan penguatan pemahaman ibu-ibu terhadap pentingnya literasi dalam keluarga sebagai tempat pertama pendidikan terjadi, serta memberikan strategi yang dapat diterapkan ibu-ibu untuk meningkatkan kecintaan anak terhadap membaca melalui pelatihan membaca nyaring. Membaca nyaring dipilih sebagai strategi yang diberikan pada masyarakat 
sasaran karena sebagaimana ditemukan dalam berbagai penelitian bahwa membaca nyaring dapat manfaat kognitif, perkembangan bahasa, kemampuan membaca, dan juga berpengaruh kuat terhadap kemampuan anak untuk mengembangkan kemampuan reseptif dalam berbahasa seperti mendengarkan dan berbicara (Ledger dan Merga, 2018). Selain manfaat tersebut, membaca nyaring juga dapat "memaksimalkan perkembangan otak dan merangsang imajinasi bayi, mempererat ikatan orang tua dan bayi, melatih daya ingat dan konsentrasi" serta tentunya meningkatkan kecintaan terhadap membaca (Setiawan, 2017). Pemilihan ibu-ibu sebagai sasaran program Ibu Baca adalah karena ibu memegang peranan utama dalam pendidikan anak (Hasan, 2004 dalam Rianawati, 2014) yang menjadi madrasah bagi anak-anaknya (https://sahabatkeluarga.kemdikbud.go.id/laman/index.php?r=tpost/xview\&id=249900802).

Dalam pelaksanaan program ini, ibu-ibu yang terlibat adalah ibu-ibu Pengurus Ranting Aisyiyah Bangunjiwo Barat dan ibu guru TK/KB di bawah naungan dan koordinasi PRA Bangunjiwo Barat. Secara demografis, peserta program ini berusia produktif yaitu 35 s.d. 45 tahun. Latar pekerjaan peserta bervariasi seperti pegawai di instansi dan badan amal usaha Muhammadiyah seperti sekolah Muhammadiyah, perawat RS Muhammadiyah dan dosen di Perguruan Tinggi Muhammadiyah, dan bekerja sebagai ibu rumah tangga dan wiraswasta seperti berdagang atau menjual makanan siap saji (warung makan). Latar belakang pendidikan peserta juga beragam, yaitu dari D3, S1 dan S2. Selain ibu-ibu usia produktif, PRA Bangunjiwo Barat juga beranggotakan ibuibu lanjut usia yang masih aktif mengikuti kajian dan kegiatan PRA.

Untuk melaksanakan program Ibu Baca, kerangka teoretis yang digunakan adalah sebagai berikut:

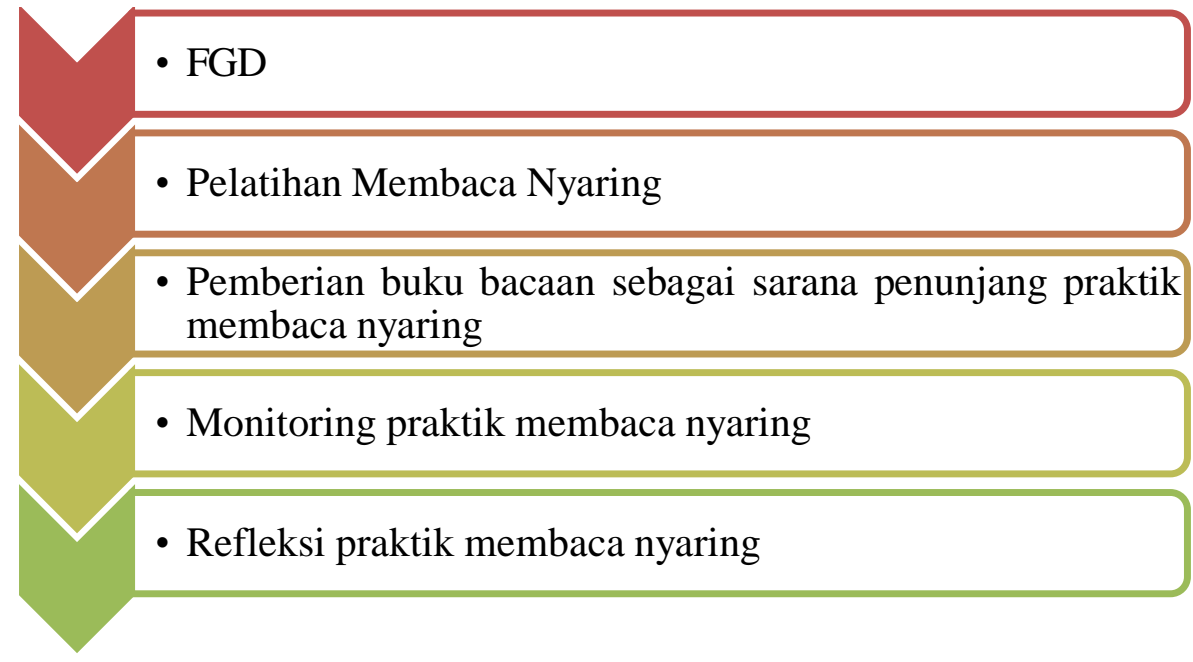

Bagan 1. Kerangka Teoretis Program Ibu Baca

\section{Metode Pelaksanaan}

Program Ibu Baca sebagai kegiatan pengabdian kepada masyarakat di PRA Bangunjiwo Barat dilakukan melalui beberapa tahap sebagaimana disajikan pada Bagan 2 berikut ini: 

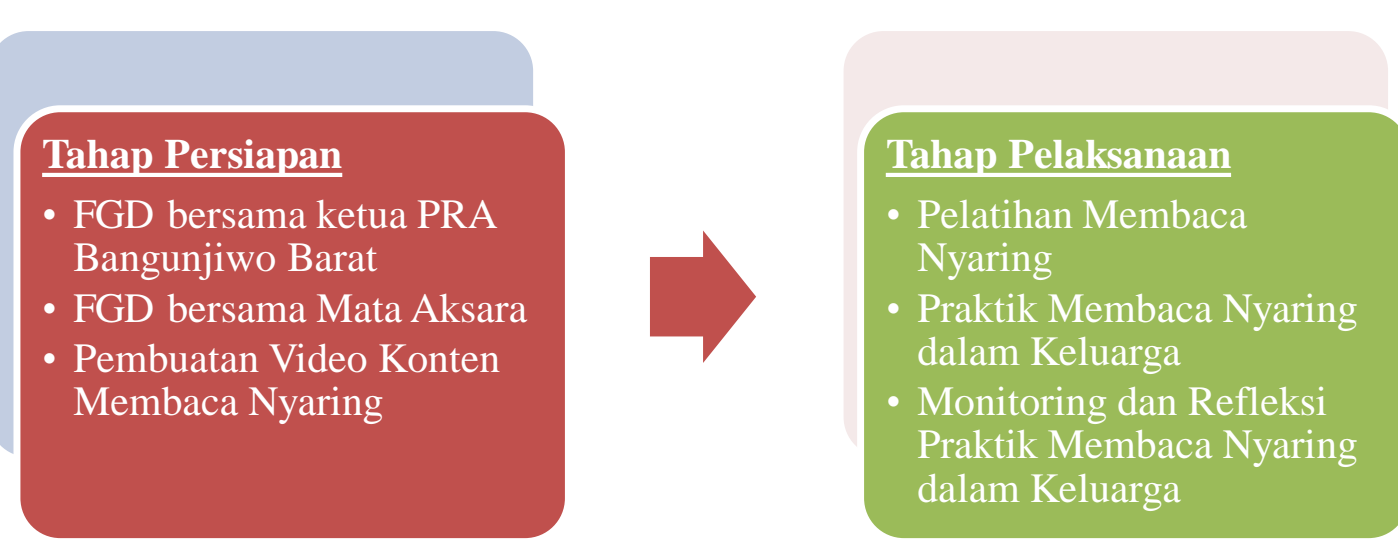

Bagan 2. Tahapan Pelaksanaan Program Ibu Baca

Program Ibu Baca diawali dengan persiapan yang mencakup FGD bersama ketua PRA Bangunjiwo Barat dan Mata Aksara. FGD bersama ketua PRA Bangunjiwo Barat dilakukan untuk merancang program bersama dan penyamaan persepsi serta tujuan pelaksanaan program. Sedangkan FGD bersama Mata Aksara dilakukan untuk mencari informasi terkait pengembangan literasi keluarga dan praktik membaca nyaring. Selain itu, Mata Aksara juga berperan sebagai narasumber dalam pelatihan membaca nyaring dan praktik pelaksanaannya dalam keluarga. Video konten Membaca Nyaring juga melibatkan Mata Aksara sebagai pemberi materi.

Setelah FGD, program dilaksanakan melalui beberapa tahapan. Tahap pertama adalah pelatihan membaca nyaring yang dilakukan secara tatap muka langsung bersama dengan Mata Aksara. Tahap kedua adalah pelaksanaan membaca nyaring di keluarga oleh peserta pelatihan. Tahap ketiga adalah monitoring dan refleksi praktik membaca nyaring yang telah dilakukan oleh peserta pelatihan. Peserta pelatihan adalah ibu-ibu PRA Bangunjiwo Barat dan guru TK/KB di bawah koordinasi PRA Bangunjiwo Barat. Keseluruhan tahapan ini dilakukan selama kurang lebih tiga bulan, yaitu September - November 2020.

\section{Hasil dan Pembahasan}

\section{Pelatihan Membaca Nyaring}

Membaca nyaring merupakan kegiatan membaca bersama yang dilakukan oleh guru, orang tua, pengasuh, ataupun orang lain kepada anak atau murid secara nyaring. Kegiatan membaca nyaring pada umumnya melibatkan penggunaan intonasi, nada, variasi kecepatan membaca dan bahasa tubuh. Untuk melakukan membaca nyaring diperlukan tiga komponen utama yaitu pembaca, yang dibacakan, dan buku untuk dibaca. Hal ini berarti bahwa membaca nyaring merupakan kegiatan yang mudah untuk dilakukan.

Di banyak penelitian, membaca nyaring memiliki banyak manfaat, terutama bagi pengembangan literasi anak di usia dini. Manfaat tersebut diantaranya adalah membantu perkembangan otak lebih optimal, memperkenalkan dan melatih kemampuan mendengar, menambah kosakata yang didengar, melatih rentang perhatian dan mengingat, mengajarkan arti kata-kata, memperkenalkan konsep media cetak/tulisan, memperkenalkan konsep gambar atau ilustrasi, merangsang imajinasi dan indra lain, memperkenalkan konsep buku dan belajar, mendekatkan orang tua dengan bayi dan mampu membuat bayi tenang, dan menjadikan teladan membaca (Setiawan, 2017). Dengan pembiasaan pengenalan buku sejak dini, anak-anak akan terbiasa serta menyukai kegiatan membaca dan menjadi pembaca sepanjang hayat. Hal ini memberikan dampak yang positif terhadap perkembangan kognitif, afektif serta perilaku anak hingga dewasa. 
Membaca nyaring dalam program Ibu Baca dikenalkan baik secara konsep maupun secara praktik oleh Mata Aksara. Mata Aksara merupakan komunitas pegiat literasi yang sudah mempraktikkan membaca nyaring dalam program literasinya. Berdasarkan pengalamannya dalam menerapkan membaca nyaring dalam keluarga dan juga sebagai fasilitator diberbagai kegiatan literasi, Mata Aksara mampu menjadi narasumber yang tepat bagi ibu-ibu peserta pelatihan.

Di dalam pelatihan, peserta diberikan informasi dan edukasi terkait pentingnya pengenalan buku sejak dini. Hal ini dimaksudkan untuk menumbuhkembangkan kecintaan anak terhadap membaca. Selain itu, peserta juga diberikan paparan terkait pentingnya menjadi role model sebagai pembaca aktif serta manfaat dari membaca nyaring untuk anak-anak baik bagi perkembangan kognitif dan kebahasaan anak tersebut maupun bagi bonding atau hubungan yang lebih erat dan hangat bagi orang tua dan anak.

Selain mendapatkan informasi dan edukasi terkait literasi keluarga dan membaca nyaring, peserta juga diberikan contoh cara membacakan nyaring serta praktik langsung membaca nyaring. Peserta diminta untuk menganalisa buku sebelum membaca kemudian berlatih dalam kelompok hingga menampilkan membaca nyaring dihadapan peserta pelatihan yang lainnya. Melalui praktik ini, peserta mendapatkan pengalaman membacakan nyaring dan mendapatkan masukan terkait praktik membacakan nyaring yang dilakukan.

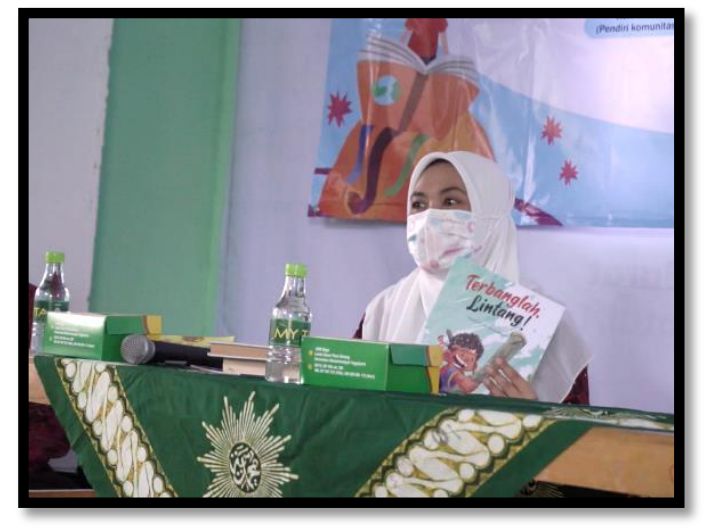

Gambar 1. Pemaparan tentang membaca nyaring oleh Mata Aksara

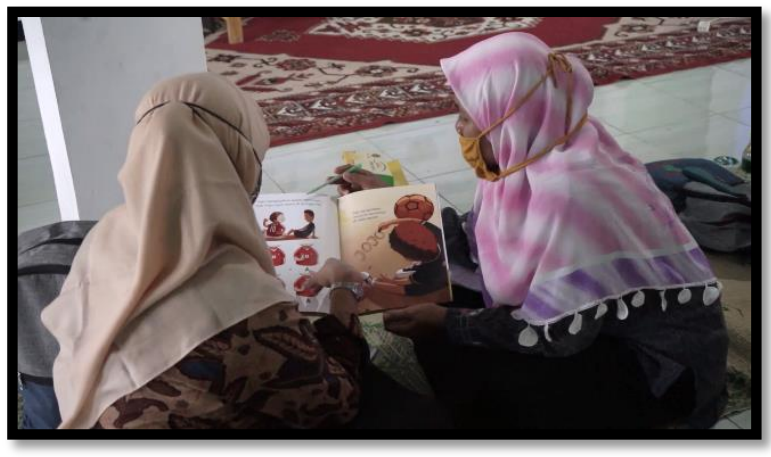

Gambar 3. Peserta pelatihan menganalisa buku bacaan

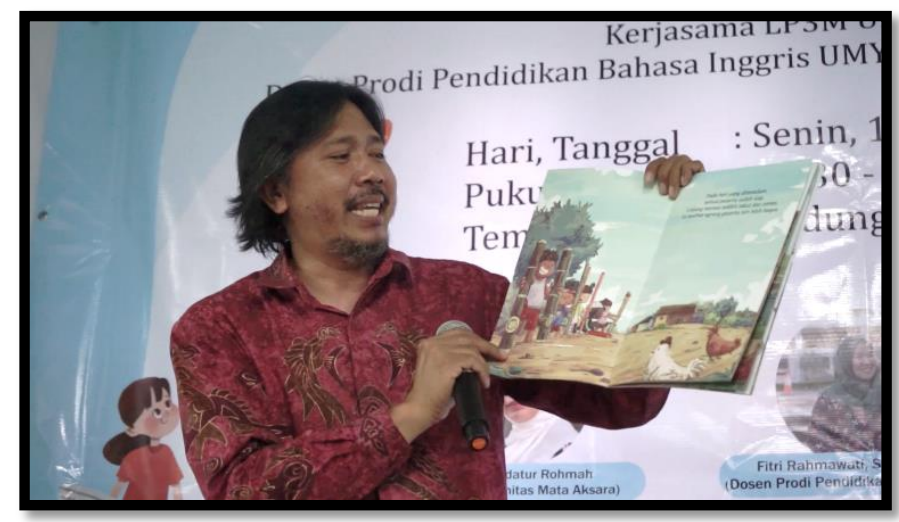

Gambar 2. Pemberian contoh membaca nyaring oleh Mata Aksara

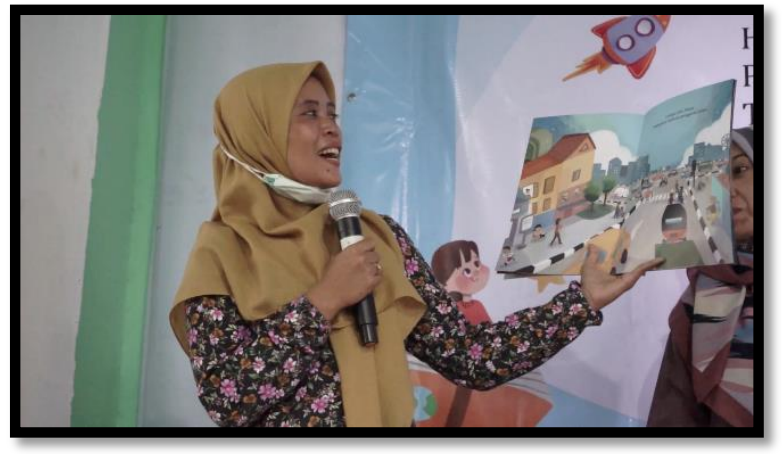

Gambar 4. Peserta pelatihan mempraktikkan membaca nyaring

\section{Pembuatan Video Konten}

Membaca nyaring sesungguhnya bukan kegiatan yang asing bagi peserta pelatihan. Pada kenyataanya, beberapa dari para peserta sudah melakukan membaca nyaring bersama anak maupun cucu mereka. Hanya saja, praktik membaca nyaring yang dilakukan peserta belum 
disertai pemahaman terkait hakikat, manfaat, teknik, dan kegiatan lanjutan dari membaca nyaring yang merupakan hal esensial setelah membaca. Selain menginformasikan hal-hal tersebut selama pelatihan, peserta juga diberikan video yang disiapkan secara khusus terkait praktik membaca nyaring. Terdapat dua video yang diberikan kepada peserta, yaitu video tentang membaca nyaring dan video terkait contoh-contoh kegiatan lanjutan yang dapat dilakukan oleh orang tua beserta anak.

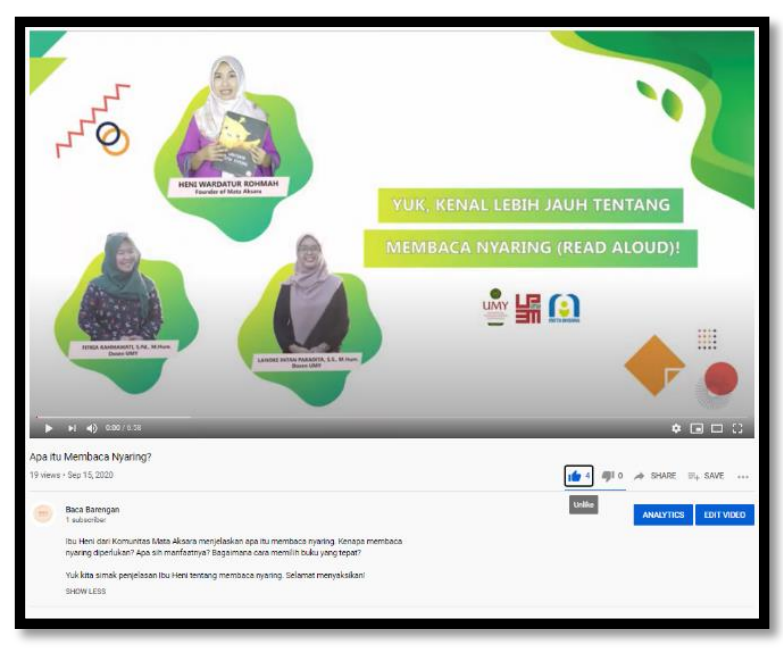

Gambar 5. Video Konten Apa Itu Membaca Nyaring (https://www.youtube.com/watch?v=F-T3F7GemEc)

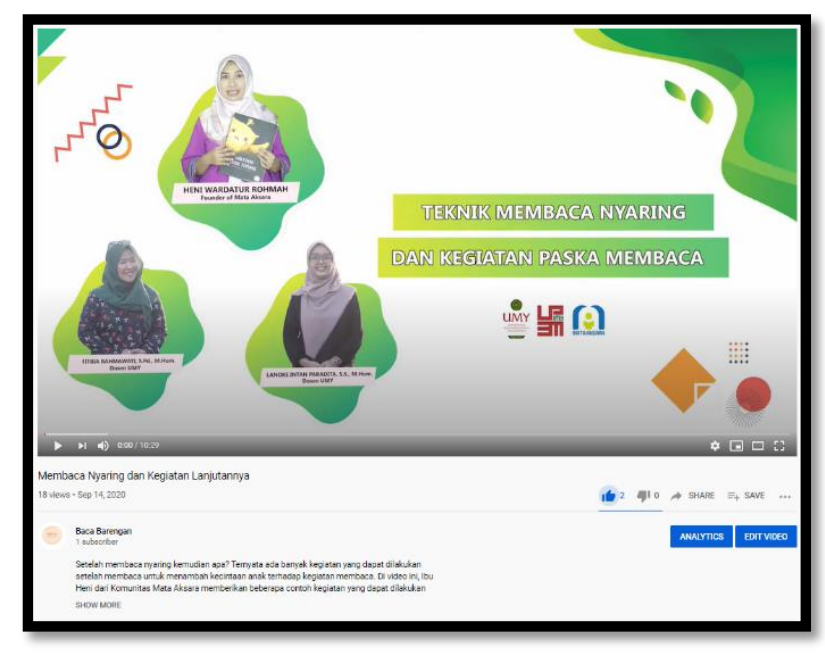

Gambar 6. Video Konten Membaca Nyaring dan Kegiatan Lanjutannya (https://www.youtube.com/watch?v=WnoBnP4kDo)

\section{Praktik Membaca Nyaring dalam Keluarga}

Setelah mengikuti pelatihan, peserta diminta untuk mempraktikkan secara langsung dalam keluarga masing-masing. Untuk menunjang pelaksanaan praktik membaca nyaring dalam keluarga, setiap peserta membawa buku cerita yang dihibahkan oleh tim pengabdi serta Mata Aksara untuk koleksi perpustakaan PRA Bangunjiwo Barat. Selain membekali peserta dengan buku fisik, para peserta juga diberikan pengantar serta contoh sumber-sumber online yang dapat digunakan untuk membaca nyaring dalam keluarga. Sumber-sumber online tersebut diantaranya adalah http://literacycloud.org/, https://www.letsreadasia.org/, dan https://storyweaver.org.in/.

Dalam program ini, para peserta juga difasilitasi untuk membagikan praktik baik membaca nyaring dalam keluarga. Fasilitasi ini berupa pembuatan whatsapp group yang digunakan sebagai media berbagi informasi terkait literasi dan juga media untuk membagikan praktik membaca nyaring yang dilakukan dalam keluarga. Dalam grup ini, diskusi juga difasilitasi oleh Mata Aksara, sehingga pertanyaan dari peserta terkait pelaksanaan membaca nyaring dapat langsung mendapatkan jawaban dari narasumber.

\section{Refleksi Pelaksanaan Membaca Nyaring}

Tahapan terakhir dalam program Ibu Baca adalah refleksi yang dilakukan oleh peserta. Refleksi ini dilakukan untuk mendapatkan tanggapan dari peserta terkait pelaksanaan program dan juga kebermanfaatnnya dalam praktik peningkatan literasi dalam keluarga terutama pada praktik membaca nyaring ibu bersama anak.

Dalam refleksi yang dibagikan oleh ibu-ibu peserta pelatihan melalui google form, 
sebagian besar peserta membacakan nyaring pada anak setiap hari sedangkan beberapa peserta lainnya membacakan nyaring diakhir minggu atau jika ada waktu longgar. Selama dua minggu semenjak pelatihan dilaksanakan, sebagian besar peserta telah membacakan dua hingga empat buku kepada anak/cucu, dan beberapa lainnya membacakan lebih dari sepuluh buku. Jumlah buku yang dibacakan tergantung pada keinginan anak untuk dibacakan buku berulang kali ataupun berganti buku. Hal ini berarti jumlah buku tidak terkait dengan frekuensi membaca nyaring oleh orang tua pada anak/cucu.

Berdasarkan refleksi dari peserta, juga diketahui bahwa ibu-ibu melakukan praktik membaca nyaring dengan memiliki pemahaman terkait manfaat dari membaca nyaring, sebagaimana ditulis oleh salah satu peserta:

"Karena cucu saya blm bs membaca dan bicaranya juga blm jelas (usia 17bln) mk sy dalam membacakan buku lebih ke merangsang kemampuan verbalnya.. Sering disela2 baca buku sy mnt cucu untk menirukan kata2 sederhana yg ada di buku..."

Salah satu peserta lain yang membacakan nyaring juga menuliskan efek yang secara langsung didapatkan oleh pembaca itu sendiri.

"Saya lebih bersemangat karena anak saya mendengarkan saya membaca cerita dan memperhatikan buku yang saya baca."

Ibu-ibu peserta pelatihan juga membagikan tanggapan anak/cucu mereka saat dibacakan secara nyaring. Sebagian besar anak/cucu merasa senang dengan praktik membaca nyaring yang dilakukan oleh ibu-ibu sehingga minta untuk dibacakan ulang. Sebagian yang lain menjadi antusias untuk membaca dan menunjukkan adanya pemahaman terhadap isi bacaan dengan lebih baik.

\section{Simpulan dan Saran}

Membaca nyaring dalam program Ibu Baca dapat digunakan sebagai salah satu kegiatan yang mendukung peningkatan literasi yang dimulai dari keluarga. Ibu sebagai madrasah utama keluarga dapat menjadi role model atau contoh nyata sebagai pembaca yang baik bagi anak. Selain itu, ibu dapat menggunakan membaca nyaring sebagai sarana untuk memberikan pendidikan secara kognitif seperti pengenalan kosakata, latihan mendengar, pengenalan gambar dan buku, serta pendekatan bonding yang hangat dan kuat antara ibu dan anak. Kegiatan membaca nyaring juga meningkatkan minat baca dan antusiasme anak-anak dalam membaca. Hal ini berarti, anak-anak mendapatkan pengalaman yang baik bersama dengan buku dan cerita. Seperti yang diungkapkan oleh Jim Trelease bahwa untuk mencetak pembaca sepanjang hayat, perlu dimulai dari anak-anak yang mengalami masa yang menyenangkan bersama buku.

Kegiatan serupa dapat dilakukan kembali di konteks yang sama. Kegiatan yang dilakukan dalam pengabdian ini belum mencakup pelatihan berulang dan pelatihan kegiatan lanjutan secara langsung. Program ini tentunya akan memberikan manfaat yang lebih baik jika pelatihan dilakukan selama beberapa sesi dengan praktik yang lebih banyak baik latihan membaca nyaring maupun kegiatan lanjutan setelah membaca. Pelatihan dengan langsung melibatkan ibu dan anak juga akan memberikan dampak yang lebih baik bagi peserta pelatihan dan bagi pengembangan literasi anak pada umumnya.

\section{Ucapan Terima Kasih}


Pada kesempatan ini kami mengucapkan terimakasih kepada:

1. LP3M UMY yang telah mendanai program pengabdian, dengan No. SK Kepala LP3M: 031/PEN-LP3M/I/2020

2. PRA Bangunjiwo Barat

3. Mata Aksara

4. Semua pihak yang telah membantu terlaksananya program pengabdian ini.

\section{Daftar Pustaka}

Ledger, S., \& Merga, M. K. (2018). Reading Aloud: Children's Attitude toward being Read to at Home and at School. Australian Journal of Teacher Education, 43(3), 124-139

Rianawati. (2014). Peran Ibu dalam Pendidikan Karakter Anak Usia Dini Menurut Pandangan Islam. Raheema: Jurnal Studi Gender dan Anak, 1(1), pp. 1-13

Setiawan, R. (2017). Membacakan Nyaring. Jakarta Selatan: Penerbit Naura

Trelease, J. (2013). The Read-Aloud Handbook ( $7^{\text {th }}$ edition). USA: Penguin Group

Sumber online:

https://gln.kemdikbud.go.id/glnsite/tentang-gln/

https://sahabatkeluarga.kemdikbud.go.id/laman/index.php?r=tpost/xview\&id=249900802 